\title{
Perceptions of students in different phases of medical education of the educational environment: Universiti Sultan Zainal Abidin
}

\author{
This article was published in the following Dove Press journal: \\ Advances in Medical Education and Practice \\ 24 March 2015 \\ Number of times this article has been viewed
}

\section{Nor Iza A Rahman \\ Aniza Abd Aziz \\ Zainal Zulkifli \\ Muhammad Arshad Haj \\ Farah Hanani Binti Mohd \\ Nasir \\ Sharvina Pergalathan \\ Muhammad Ismail Hamidi \\ Salwani Ismail \\ Nordin Bin Simbak \\ Mainul Haque}

Faculty of Medicine, Universiti Sultan

Zainal Abidin, Kuala Terengganu,

Terengganu, Malaysia
Correspondence: Mainul Haque Faculty of Medicine and Health Sciences, Universiti Sultan Zainal Abidin, Kampus Kota, Jalan Sultan Mahmud, 20400 Kuala Terengganu, Terengganu, Malaysia Email runurono@gmail.com
Background: The Dundee Ready Education Environment Measure (DREEM) was planned and designed to quantify the educational environment precisely for medical schools and health-related professional schools. DREEM is now considered a valid and reliable tool, which is globally accepted for measuring the medical educational environment. The educational environment encountered by students has an impact on satisfaction with the course of study, perceived sense of well-being, aspirations, and academic achievement. In addition to being measurable, the educational environment can also be changed, thus enhancing the quality of medical education and the environment, and the medical education process. The objective of this study was to assess the educational environment of the Universiti Sultan Zainal Abidin (UniSZA) undergraduate medical program from the students' perspective. The study expected to explore UniSZA medical students' overall perceptions, perceptions of learning, teachers, atmosphere, academic self-perception, and social self-perception using the DREEM questionnaire.

Methods: A cross-sectional survey was conducted to study the perceptions of the students toward the educational environment of UniSZA as a new medical school, using the DREEM questionnaire. All medical students of UniSZA from Years I-V enrolled in the Bachelor of Medicine and Bachelor of Surgery programs were the target population $(n=270)$. Therefore, the universal sampling technique was used. The data were analyzed using the SPSS 20 software. This study obtained ethical clearance from the Faculty of Medicine and Health Sciences, UniSZA.

Results: A total of 195 out of 270 students responded. Respondents included 31\% males and $69 \%$ females. The overall DREEM scores were significantly higher $(P<0.001)$ for females than males.

Conclusion: The medical students at UniSZA showed a positive perception of their educational environment. The new medical faculty, established for only a few years, has achieved an above-average, conducive educational environment for students. Most of the students showed a positive perception for the entire five domains tested in the DREEM survey. Females were consistently satisfied with UniSZA's educational environment, and self-perception was high, as compared to male undergraduates.

Keywords: perceptions, medical students, educational environment, DREEM, UniSZA

\section{Introduction}

Medical education (ME) is considered as highly demanding in almost all societies and countries. ME and professional conduct as aspects of university life are considered as very complex and stressful. ${ }^{1-8}$ Students and medical doctors need to achieve the 
development of exclusive and wide-ranging skills and aptitudes to meet demands of patients and communities that they serve..$^{1-8}$

Environment is the sum total of what is around something or someone. It includes living things and natural forces. The environment of living things provides conditions for development and growth. It can also cause danger and damage. ${ }^{9}$

"The ME environment ideally should foster intellectual activities and progression, while at the same time encouraging friendliness, co-operation and support." 10 A number of researchers have reported that encouraging and enlightening settings are very important determinants for medical students for their development as more holistic and rational prescribers. ${ }^{4,11-20}$ There has been an exigent requisite to define educational environment. ${ }^{21-27}$ Some educational scientists from Malaysia feel that the

[...] educational environment is a broad concept where education encompasses both teaching and learning while environment encompasses everything that surrounds us.

Educational environment can be described as anything surrounds an educational institution. ${ }^{28}$

Similarly, there has been an urgent need for the development of a valid and reliable instrument for the measurement of the educational environment. ${ }^{21-27,29}$ Again, appraisal of the total environment of a medical school is very important to ensure the optimum standard of high-quality ME. ${ }^{29-31}$

The Dundee Ready Education Environment Measure (DREEM) was planned and designed to precisely quantify the educational environment for medical schools and healthrelated professional schools. ${ }^{19,32}$ DREEM is now considered a valid and reliable tool, which is globally accepted for measuring the ME environment. ${ }^{19,32,33}$ Therefore, throughout the world, the DREEM questionnaire has been used, and many studies' findings have been published in highly reputed journals. ${ }^{15,17,19,32,34-40}$ A numbers of studies have also been conducted in Malaysian medical schools. ${ }^{28,29,41-44}$

The educational environment encountered by students has an impact on satisfaction with the course of study, perceived well-being, aspirations, and academic achievement. ${ }^{45-47}$ In addition to being measurable, the educational environment can also be changed, thus enhancing the quality of the environment and the ME process. ${ }^{48}$ Various methodologies have been utilized to investigate educational climate. Studies about educational climate date back to the 1970s. In 1970, Rothman et al from the University of Toronto developed the Learning Environment Questionnaire. ${ }^{21}$ The DREEM questionnaire was originally used to evaluate the learning environments of medical students, whose course curriculum had rapidly changed during a period of major reforms in traditional teaching methods up until and during the 1990s. There are other related tools, including the precursor to DREEM, the ME Environment Measure, and several subsequent tools that have been designed to measure the educational environment in specific post-graduate medical settings: the Post-graduate Hospital Educational Environment Measure, the Surgical Theatre Educational Environment Measure, and the Anesthetic Theatre Educational Environment Measure. ${ }^{49}$

DREEM was published in 1997 as a tool to evaluate educational environments of medical schools and other health training settings and a recent review concluded that it was the most suitable such instrument. ${ }^{49}$

A Delphi technique, involving a panel of 30 faculty members from around the world, was used to generate criteria indicative of desirable education climates for health professions in light of the new curriculum standards..$^{50}$

DREEM was then refined into a 50-item self-report questionnaire using a 5-point Likert scale, ${ }^{51}$ with scores reflecting a student's overall perception of the environment and their perceptions of five main aspects of this environment, namely: 1) their learning, 2) the teachers, 3) academic self-perception, 4) atmosphere, and 5) social self-perception. ${ }^{50,52}$

DREEM has been translated to eight languages and has been used in at least 20 countries. This questionnaire has been applied globally to a number of undergraduate medical schools. ${ }^{53}$ In fact, the DREEM questionnaire is an ideal instrument for examining students' opinions. It is valuable in highlighting areas of concern voiced by medical students, including educational climate, academic achievement, and social support. A systematic review of 79 original articles concluded that DREEM is "likely to be the most suitable instrument for undergraduate medicine, postgraduate medicine, nursing and dental education". ${ }^{54}$

The medical faculty of the Universiti Sultan Zainal Abidin (UniSZA) has evolved with time. It initially started as a faculty of health sciences offering three diploma programs in Radiography, Medical Laboratory Technology, and Nursing Science. UniSZA was honored with the trust given by the Ministry of Higher Education of the Government of Malaysia to contribute toward the development and improvement of health care by the approval of the university's medical program in Kuala Terengganu, Terengganu, Malaysia. The approval was granted by the Ministry of Higher Education on February 3, 2009. Faculty had already started one degree program, Dietetics (Honors) in 2008; a Bachelor of Medicine and Bachelor of 
Surgery (MBBS) became part of the program in 2009. In 2011, a Diploma in Physiotherapy was added to existing diploma programs. It is expected that faculty will admit new groups of students in 2015 into another three new programs: 1) Bachelor of Biomedicine, 2) Bachelor of Medical Imaging and Diagnostics, 3) Bachelor of Nutrition. The first group of 30 MBBS students, admitted in 2009, graduated in August 2014. It is expected that UniSZA graduates will start working as House Officers and serving Malaysia by as early as 2015 .

The objective of this study was to assess the educational environment of the UniSZA undergraduate medical program from the students' perspective. The researchers expected to explore UniSZA medical students' overall perception, and perceptions of learning, teachers, atmosphere, academic selfperception, and social self-perception, using the DREEM questionnaire. The current work will also determine the association between UniSZA medical students' socio-demographic and educational characteristics overall and based on five subscales of the DREEM questionnaire.

\section{Materials and methods}

A cross-sectional survey was conducted to study the perception of the students toward the educational environment of UniSZA as a new medical school. Throughout the world and in different medical schools of both developed and developing countries, DREEM has been extensively utilized as an instrument to collect evidence about educational environment. ${ }^{15,17,19,28,29,32,34-44,55,56}$ The DREEM instrument was first developed at the University of Dundee, and it now provides and achieves validation as a global, generic "diagnostic inventory for measuring the quality of educational environment". ${ }^{32,53}$

DREEM is a 50 -item inventory, consisting of five subscales. 1) students' perceptions of learning (SPL) - 12 items, maximum score of 48;2) students' perceptions of teachers (SPT) - eleven items, maximum score of $44 ; 3$ ) students' academic self-perceptions (SASP) - eight items, maximum score of 32; 4) students' perceptions of atmosphere (SPA) 12 items, maximum score of 48; and 5) students' social selfperceptions (SSSP) - seven items, maximum score of 28. The total score for all subscales is 200 (Table 1). However, negative items were scored in reverse for analysis so that the higher the score, the more negative the feedback, or the more incorrect perception.

All medical students of UniSZA from Years I-V of the MBBS program were the target population. The total number of students participating was 270 . Therefore, the universal sampling technique was used. The DREEM questionnaires were distributed among the study subjects, who were given
Table I Guide of DREEM score categories and interpretation according to domain ${ }^{12}$

\begin{tabular}{lll}
\hline Domain & Score & Interpretation \\
\hline SPL & $0-12$ & Very poor \\
& $13-24$ & Teaching is viewed negatively \\
& $25-36$ & A more positive approach \\
& $37-48$ & Teaching highly thought of \\
SPT & $0-11$ & Abysmal \\
& $12-22$ & In need of some retraining \\
& $23-33$ & Moving in the right direction \\
& $34-44$ & Model teachers \\
SASP & $0-8$ & Feeling of total failure \\
& $9-16$ & Many negative aspects \\
& $17-24$ & Feeling more on the positive side \\
& $25-32$ & Confident \\
SPA & $0-12$ & A terrible environment \\
& $13-24$ & There are many issues that need changing \\
& $25-36$ & A more positive atmosphere \\
& $37-48$ & A good feeling overall \\
SSSP & $0-7$ & Miserable \\
& $8-14$ & Not a nice place \\
& $15-21$ & Not too bad \\
& $22-28$ & Very good socially
\end{tabular}

Abbreviations: SPL, students' perceptions of learning; SPT, students' perceptions of teaching; SASP, students' academic self-perceptions; SPA, students' perceptions of atmosphere; SSSP, students' social self-perceptions; DREEM, the Dundee Ready Education Environment Measure.

1 day to complete them. The data were collected in July 2014. Explanation about the purpose of the study was given, and consent was obtained from every student. The questionnaires were then retrieved. The completed questionnaires were collated for further analysis. The data were analyzed using SPSS version 20 software using descriptive statistics; the numerical variables were described using means and standard deviations (SD), and categorical variables were presented in frequencies and percentages. The Independent $t$-test was applied for comparison between two means variables, which included sex, phase of study, and type of secondary school. Analysis of variance (ANOVA) was used for comparison of more than two means, which included race, marital status, cumulative grade point average, type of foundation study, and year of study.

There are four methods available to students to pursue a degree program in Malaysia. The Ministry of Education conducts two major programs to enter degree programs: The first method allows students to matriculate after secondary school. This program is usually a 1-year program, but it may extend up to 2 years if necessary. The majority of UniSZA students have completed the 1-year matriculation program. The second method is the Malaysia Certificate of Higher Education, which is a 1.5 -year program. In addition, a 1-year foundation training is conducted by select Malaysian Universities. Finally, students can opt to complete 
a diploma after secondary school designed for entry into a degree program.

This study obtained ethical clearance from the Faculty of Medicine and Health Sciences, recorded as Memo Number UniSZA.NI 1 1628-1 J ld.2 (9) and dated October 27, 2014. As the current study was based on a questionnaire, no intervention with human or animal was required. UniSZA did not provide any funding to conduct this study. Therefore, the ethical committee initially provided the authors with verbal permission to conduct the study, pending formal written authorization.

\section{Results}

Demographic data of the current study are described in Table 2. A total of 195 (72\%) out of 270 students responded to the questionnaire. Specifically, the response rate according to year consisted of Year I (55 students, or 28\%); Year II

Table 2 Demographic profiles of respondents $(n=195)$

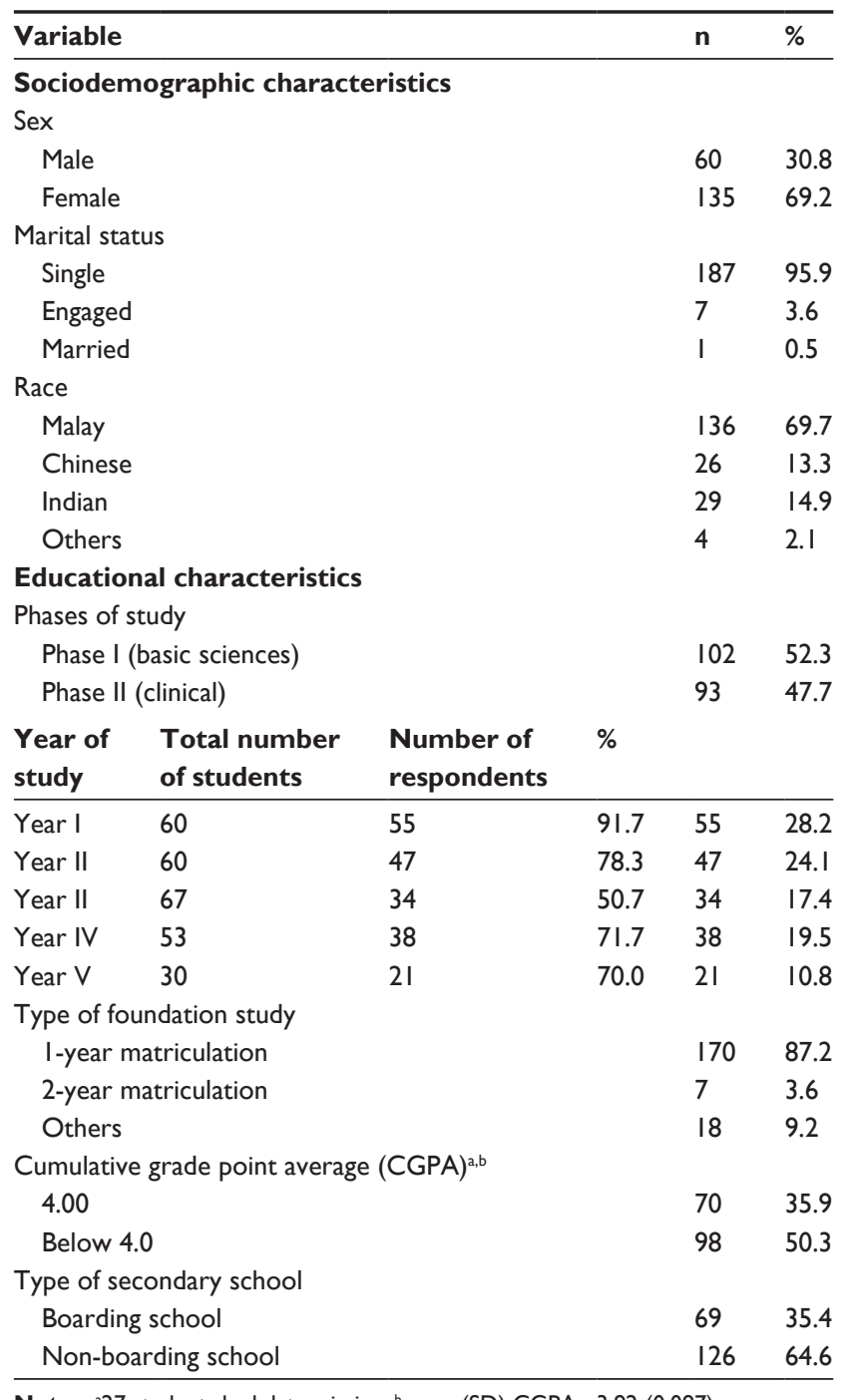

Notes: 227 students had data missing; ${ }^{b}$ mean (SD) CGPA $=3.92$ (0.097).

Abbreviation: SD, standard deviation.
(47 students, or 24\%); Year III (34 students, or 17\%); Year IV (38 students, or $20 \%$ ); and Year V (21 students, or $11 \%$ ) responses (Table 2$)$. There were both male $(60$, or $31 \%$ ) and female $(135$, or $69 \%)$ study respondents. Most of them (187, or $96 \%$ ) were single, and the remaining eight students (4\%) were either engaged or married. The majority of the medical students were Malays (136, or 70\%), followed by Chinese (26 students, or 13\%), Indians (29 students, or 15\%), and other races (four student respondents, or 2\%). Fifty-five respondents (28\%) were recruited from the Year I population, and the least represented at 21 respondents $(11 \%)$ were Year $\mathrm{V}$ students. Most students (65\%) were from non-boarding schools, and the remaining 69 students $(35 \%)$ came to the university from boarding schools (Table 2).

The five items from the DREEM questionnaire with the highest mean score were derived from the SPT, SASP, and SSSP domains. SPT item 2 scored a mean of $3.39 \pm 0.568$ points, and item 40 scored $3.10 \pm 0.725$ points. SASP item 31 scored a mean of $3.06 \pm 0.652$ points, and item 45 achieved $3.05 \pm 0.612$ points. SSSP item 15 garnered $3.14 \pm 0.806$ points. Items scored at less than 2.0 were items belonging to the SPL, SASP, and SSSP domains. In the SPL domain, item 25 achieved just $1.49 \pm 0.833$ points; SASP item 27 scored only $1.67 \pm 0.895$ points; SSSP item 3 received only $1.98 \pm 0.922$ points, and item 14 in the same domain scored only $1.97 \pm 1.04$ points (Table 3). A total of nine items engendered negative statements, and scores for these items varied from $1.49 \pm 0.833$ to $2.39 \pm 0.985$ points (Table 3 ). The distribution of negative statements was as follows: the SPL domain received two negative responses, the SPT domain had four, and the SASP domain had no negative statements. Furthermore, the SPA domain accounted for two negative statements, and the SSSP domain accounted for a single negative statement.

The mean DREEM scores were $128.2 \pm 17.46$ for preclinical and $127.5 \pm 15.65$ points for clinical students (Table 4 ). Pre-clinical students scored slightly higher than clinical students, but there were no statistically significant differences $(P=0.386)$ (Table 5). A minimal difference was also found according to subscale scores.

The scores for all five subscales (Table 6) illustrate respondents' positive perceptions, and the interpretation of responses suggested by the DREEM scoring system. ${ }^{57}$ In general, the majority of students perceived their learning experience as positive (84\%) and the teaching as appropriate (79\%); students felt positive in their academic self-perceptions $(81 \%)$, and, for the most part, agreed that the learning atmosphere was positive (83\%). They also perceived that their social surroundings were acceptable 
Table 3 The mean item score of DREEM by medical students of UniSZA $(n=195)$, and description of DREEM by medical students of UniSZA according to academic phases

\begin{tabular}{|c|c|c|}
\hline Domain & Item & Mean (SD) \\
\hline \multicolumn{3}{|l|}{$\overline{S P L}$} \\
\hline 1 & I am encouraged to participate & $2.80(0.660)$ \\
\hline 7 & The teaching is often stimulating & $2.81(0.748)$ \\
\hline 13 & The teaching is student-centered & $2.65(0.761)$ \\
\hline 16 & The teaching is helpful to develop my skills/competency & $2.99(0.725)$ \\
\hline 20 & The teaching is well focused & $2.86(0.666)$ \\
\hline 22 & The teaching is sufficient to develop my confidence & $2.55(0.800)$ \\
\hline 24 & The teaching time is put to good use & $2.74(0.731)$ \\
\hline 25 & The teaching over-emphasizes factual learning* & $1.49(0.833)$ \\
\hline 38 & I am clear about the learning objectives of the course & $2.84(0.681)$ \\
\hline 44 & The teaching encourages me to be an active learner & $2.83(0.806)$ \\
\hline 47 & Long-term learning is emphasized over short-term learning & $2.72(0.770)$ \\
\hline 48 & The teaching is too teacher-centered* & $2.30(0.784)$ \\
\hline \multicolumn{3}{|l|}{ SPT } \\
\hline 2 & The teachers are knowledgeable & $3.39(0.568)$ \\
\hline \multirow[t]{2}{*}{6} & The teachers place emphasis on being patient-centered during their & $2.87(0.748)$ \\
\hline & interaction with patients & \\
\hline 8 & The teachers ridicule the students* & $2.46(0.838)$ \\
\hline 9 & The teachers are authoritarian* & $2.06(0.851)$ \\
\hline 18 & The teachers have good communication skills with the patients & $2.80(0.777)$ \\
\hline 29 & The teachers are good at providing feedback to students & $2.65(0.869)$ \\
\hline 32 & The teachers provide constructive criticism here & $2.59(0.810)$ \\
\hline 37 & The teachers give clear examples & $2.87(0.657)$ \\
\hline 39 & The teachers get angry in class* & $2.39(0.985)$ \\
\hline 40 & The teachers are well prepared for their classes & $3.10(0.725)$ \\
\hline 50 & The students irritate the teachers* & $2.11(0.994)$ \\
\hline \multicolumn{3}{|c|}{ 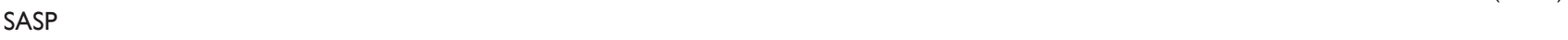 } \\
\hline 5 & Learning strategies which work for me before, continue to work for me now & $2.53(0.875)$ \\
\hline 10 & I am confident about passing this year & $2.53(0.833)$ \\
\hline 21 & I feel I am well prepared for my profession & $2.10(0.825)$ \\
\hline 26 & Last year's work has been a good preparation for this year's work & $2.46(0.768)$ \\
\hline 27 & I am able to memorize all I need & $1.67(0.895)$ \\
\hline 31 & I have learned a lot about empathy in my profession & $3.06(0.652)$ \\
\hline 41 & My problem-solving skills are well developed here & $2.78(0.707)$ \\
\hline 45 & Much of what I have to learn seems relevant to my career in health care & $3.05(0.612)$ \\
\hline \multicolumn{3}{|c|}{ (2) } \\
\hline 11 & The atmosphere was relaxed during ward teaching & $2.02(0.885)$ \\
\hline 12 & The school is well timetabled & $2.26(1.06)$ \\
\hline 17 & Cheating is a problem in this school* & $2.36(1.04)$ \\
\hline 23 & The atmosphere is relaxed during lectures & $2.58(0.872)$ \\
\hline 30 & There are opportunities for me to develop interpersonal skills & $2.93(0.659)$ \\
\hline 33 & I feel comfortable in class socially & $2.84(0.718)$ \\
\hline 34 & The atmosphere is relaxed during seminars/tutorials & $2.62(0.849)$ \\
\hline 35 & I found the experience disappointing* & $2.39(0.980)$ \\
\hline 36 & I am able to concentrate well & $2.52(0.789)$ \\
\hline 42 & The enjoyment outweighs the stress of studying medicine & $2.31(0.929)$ \\
\hline 43 & The atmosphere motivates me as a learner & $2.70(0.821)$ \\
\hline 49 & I feel able to ask the questions I want & $2.70(0.821)$ \\
\hline \multicolumn{3}{|c|}{ 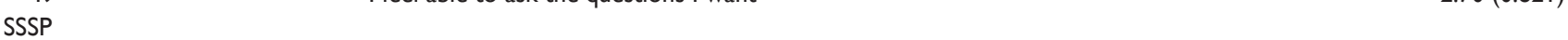 } \\
\hline 3 & There is a good support system for students who get stressed & $1.98(0.922)$ \\
\hline 4 & I am too tired to enjoy this course & $2.21(0.985)$ \\
\hline 14 & I am rarely bored on this course* & $1.97(1.04)$ \\
\hline 15 & I have good friends in this school & $3.14(0.806)$ \\
\hline 19 & My social life is good & $2.76(0.928)$ \\
\hline 28 & I seldom feel lonely & $2.18(1.05)$ \\
\hline 46 & My accommodation is pleasant & $2.35(0.937)$ \\
\hline
\end{tabular}

Note: *Represents items as negative statements.

Abbreviations: SPL, students' perceptions of learning; SPT, students' perceptions of teaching; SASP, students' academic self-perceptions; SPA, students' perceptions of atmosphere; SSSP, students' social self-perceptions; SD, standard deviation; DREEM, the Dundee Ready Education Environment Measure; UniSZA, Universiti Sultan Zainal Abidin. 
Table 4 Domain mean score of DREEM by medical students of UniSZA according to academic phase $(n=195)$

\begin{tabular}{|c|c|c|c|}
\hline \multirow[t]{2}{*}{ Domain } & \multicolumn{3}{|l|}{ Mean (SD) } \\
\hline & Pre-clinical & Clinical & Overall \\
\hline Students' perceptions of learning (SPL) ${ }^{\mathrm{a}}$ & $31.3(4.97)$ & $31.8(4.07)$ & $31.6(4.56)$ \\
\hline Students' perceptions of teaching (SPT) ${ }^{\mathrm{b}}$ & $29.4(4.26)$ & $29.1(4.69)$ & $29.3(4.46)$ \\
\hline Students' academic self-perceptions (SASP) ${ }^{c}$ & $20.1(3.31)$ & $20.2(3.42)$ & $20.1(3.35)$ \\
\hline Students' perceptions of atmosphere (SPA) ${ }^{\mathrm{a}}$ & $30.5(5.42)$ & $30.0(4.61)$ & $30.2(5.04)$ \\
\hline Students' social self-perceptions (SSSP) ${ }^{d}$ & $16.9(3.44)$ & $16.3(2.83)$ & $16.6(3.18)$ \\
\hline Total DREEM score & $128.2(17.46)$ & $127.5(15.65)$ & $127.9(16.58)$ \\
\hline
\end{tabular}

Notes: ${ }^{\text {Minimum score }}=0$, maximum score $=48$; ${ }^{b}$ minimum score $=0$, maximum score $=44 ;{ }^{c}$ minimum score $=0$, maximum score $=32$; ${ }^{d}$ minimum score $=0$, maximum score $=28$; ${ }^{\text {minimum score }}=0$, maximum score $=200$ points.

Abbreviations: DREEM, the Dundee Ready Education Environment Measure; UniSZA, Universiti Sultan Zainal Abidin; SD, standard deviation.

Table 5 Summary of association between social demographic and educational characteristics with mean score of DREEM by medical students of UniSZA $(n=195)$

\begin{tabular}{|c|c|c|c|c|c|c|c|}
\hline \multirow[t]{2}{*}{ Variable } & \multirow[t]{2}{*}{$\mathbf{n}$} & \multicolumn{6}{|l|}{ Mean (SD) } \\
\hline & & Overall & SPL & SPT & SASP & SPA & SSSP \\
\hline \multicolumn{8}{|c|}{ Sociodemographic characteristics } \\
\hline \multicolumn{8}{|l|}{ Sex ${ }^{f}$} \\
\hline Male & 60 & $120.7(17.9)^{d}$ & $29.8(5.37)^{d}$ & $27.3(4.320)^{d}$ & $19.1(3.93)^{c}$ & $29.1(5.59)^{\mathrm{a}}$ & $15.3(3.15)^{\mathrm{d}}$ \\
\hline Female & 135 & $|3| . \mid(14.9)^{\mathrm{d}}$ & $32.4(3.92)^{d}$ & $30.6(4.25)^{d}$ & $20.6(2.96)^{c}$ & $30.7(4.7 \mathrm{I})^{\mathrm{a}}$ & $17.2(3.01)^{\mathrm{d}}$ \\
\hline \multicolumn{8}{|l|}{ Marital status ${ }^{g}$} \\
\hline Single & 187 & $127.8(16.8)^{\mathrm{e}}$ & $31.6(4.61)^{\mathrm{e}}$ & $29.3(4.50)^{\mathrm{e}}$ & $20.1(3.40)^{\mathrm{e}}$ & $30.2(5.08)^{\mathrm{e}}$ & $16.6(3.22)^{\mathrm{e}}$ \\
\hline Engaged & 7 & $129.3(11.6)^{\mathrm{e}}$ & $31.3(3.77)^{\mathrm{e}}$ & $28.6(3.64)^{\mathrm{e}}$ & $20.9(2.19)^{\mathrm{e}}$ & $32.3(4.11)^{\mathrm{e}}$ & $16.3(2.06)^{\mathrm{e}}$ \\
\hline Married & 1 & $131.0(0)^{\mathrm{e}}$ & $31.0(0)^{\mathrm{e}}$ & $31.0(0)^{\mathrm{e}}$ & $20.0(0)^{e}$ & $32.0(0)^{\mathrm{e}}$ & $17.0(0)^{\mathrm{e}}$ \\
\hline \multicolumn{8}{|l|}{ Race $^{g}$} \\
\hline Malay & 136 & $127.7(14.3)^{\mathrm{e}}$ & $31.8(3.94)^{\mathrm{e}}$ & $29.2(4.20)^{\mathrm{e}}$ & $20.1(2.98)^{\mathrm{e}}$ & $30.0(4.47)^{b}$ & $16.5(2.75)^{\mathrm{e}}$ \\
\hline Chinese & 26 & $123.3(22.9)^{\mathrm{e}}$ & $30.2(6.20)^{\mathrm{e}}$ & $28.3(5.06)^{\mathrm{e}}$ & $20.2(4.56)^{\mathrm{e}}$ & $28.5(6.50)^{b}$ & $16.1(4.21)^{\mathrm{e}}$ \\
\hline Indian & 29 & $133.6(19.9)^{\mathrm{e}}$ & $31.5(5.65)^{\mathrm{e}}$ & $30.5(5.08)^{\mathrm{e}}$ & $20.5(3.88)^{\mathrm{e}}$ & $33.0(5.5 \mathrm{I})^{\mathrm{b}}$ & $17.6(3.99)^{\mathrm{e}}$ \\
\hline Others & 4 & $124.8(4.35)^{\mathrm{e}}$ & $31.6(4.56)^{\mathrm{e}}$ & $29.3(3.59)^{\mathrm{e}}$ & $20.3(3.40)^{\mathrm{e}}$ & $28.5(2.08)^{b}$ & $15.3(0.96)^{\mathrm{e}}$ \\
\hline \multicolumn{8}{|c|}{ Educational characteristics } \\
\hline \multicolumn{8}{|l|}{ Phases of study ${ }^{f}$} \\
\hline Phase I (pre-clinical) & 102 & $128.2(17.5)^{e}$ & $31.3(4.97)^{\mathrm{e}}$ & $29.4(4.26)^{\mathrm{e}}$ & $20.1(3.31)^{\mathrm{e}}$ & $30.5(5.42)^{\mathrm{e}}$ & $16.9(3.45)^{\mathrm{e}}$ \\
\hline Phase II (clinical) & 93 & $127.5(15.7)^{\mathrm{e}}$ & $31.8(4.07)^{\mathrm{e}}$ & $29.2(4.69)^{\mathrm{e}}$ & $20.2(3.42)^{\mathrm{e}}$ & $30.0(4.61)^{\mathrm{e}}$ & $16.3(2.83)^{\mathrm{e}}$ \\
\hline \multicolumn{8}{|l|}{ Year of Studyg } \\
\hline Year I & 55 & $129.4(18.2)^{e}$ & $31.4(5.17)^{\mathrm{e}}$ & $30.1(4.43)^{\mathrm{e}}$ & $19.9(3.48)^{\mathrm{e}}$ & $31.4(5.79)^{\mathrm{e}}$ & $16.5(3.38)^{e}$ \\
\hline Year II & 47 & $126.9(16.6)^{\mathrm{e}}$ & $31.2(4.79)^{\mathrm{e}}$ & $28.6(3.93)^{\mathrm{e}}$ & $20.4(3.11)^{\mathrm{e}}$ & $29.3(4.76)^{\mathrm{e}}$ & I7.3 $(3.5 \mathrm{I})^{\mathrm{e}}$ \\
\hline Year III & 34 & $130.8(15.8)^{\mathrm{e}}$ & $32.1(4.08)^{\mathrm{e}}$ & $30.3(4.77)^{\mathrm{e}}$ & $21.2(3.16)^{\mathrm{e}}$ & $30.7(4.5 \mathrm{I})^{\mathrm{e}}$ & $16.4(2.84)^{\mathrm{e}}$ \\
\hline Year IV & 38 & $127.1(12.1)^{\mathrm{e}}$ & $31.8(3.82)^{\mathrm{e}}$ & $28.9(4.13)^{\mathrm{e}}$ & $19.9(3.13)^{\mathrm{e}}$ & $29.8(3.8 \mathrm{I})^{\mathrm{e}}$ & $16.7(2.38)^{\mathrm{e}}$ \\
\hline Year V & 21 & $123.3(20.3)^{\mathrm{e}}$ & $31.7(4.56)^{\mathrm{e}}$ & $27.7(5.22)^{\mathrm{e}}$ & $19.2(4.04)^{\mathrm{e}}$ & $29.3(6.00)^{\mathrm{e}}$ & I5.4 (3.47) \\
\hline \multicolumn{8}{|l|}{ Type of foundation study ${ }^{\mathrm{g}}$} \\
\hline I-year matriculation & 170 & $127.6(16.6)^{e}$ & $31.6(4.46)^{\mathrm{e}}$ & $29.2(4.43)^{\mathrm{b}}$ & $20.0(3.4 \mathrm{I})^{\mathrm{e}}$ & $30.2(5.16)^{\mathrm{e}}$ & $16.5(3.15)^{\mathrm{e}}$ \\
\hline 2-year matriculation & 7 & $119.9(5.40)^{\mathrm{e}}$ & $29.3(2.69)^{\mathrm{e}}$ & $25.6(3.15)^{b}$ & $20.7(1.11)^{\mathrm{e}}$ & $28.4(2.07)^{\mathrm{e}}$ & $15.9(2.11)^{\mathrm{e}}$ \\
\hline Others & 18 & $134.2(17.7)^{\mathrm{e}}$ & $32.3(4.56)^{\mathrm{e}}$ & $31.7(4.04)^{\mathrm{b}}$ & $21.2(3.24)^{\mathrm{e}}$ & $31.4(4.57)^{\mathrm{e}}$ & $17.6(3.70)^{\mathrm{e}}$ \\
\hline \multicolumn{8}{|c|}{ Cumulative grade point average (CGPA) } \\
\hline 4.00 & 70 & $127.5(20.3)^{\mathrm{e}}$ & $31.7(5.17)^{\mathrm{e}}$ & $29.1(5.03)^{\mathrm{e}}$ & $20.2(3.77)^{\mathrm{e}}$ & $30.3(6.09)^{\mathrm{e}}$ & $16.7(3.87)^{\mathrm{e}}$ \\
\hline Below 4.0 & 98 & $128.0(14.9)^{\mathrm{e}}$ & $31.8(4.48)^{\mathrm{e}}$ & $29.5(4.33)^{\mathrm{e}}$ & $20.1(3.21)^{\mathrm{e}}$ & $30.3(4.55)^{\mathrm{e}}$ & $16.4(2.68)^{\mathrm{e}}$ \\
\hline \multicolumn{8}{|l|}{ Type of secondary schoolf } \\
\hline Boarding school & 69 & $126.7(13.3)^{e}$ & $31.7(3.54)^{\mathrm{e}}$ & $29.2(3.99)^{\mathrm{e}}$ & $19.8(2.99)^{\mathrm{e}}$ & $29.9(4.29)^{\mathrm{e}}$ & I6.I $(2.20)^{\mathrm{e}}$ \\
\hline Non-boarding school & 126 & $128.6(18.1)^{e}$ & $31.5(5.04)^{\mathrm{e}}$ & $29.3(4.7 \mathrm{I})^{\mathrm{e}}$ & $20.4(3.53)^{\mathrm{e}}$ & $30.5(5.42)^{\mathrm{e}}$ & $16.9(3.58)^{\mathrm{e}}$ \\
\hline
\end{tabular}

Notes: a ${ }^{2}$ tatistically significant at $P<0.05$; ' bignificant at $P<0.01$; chighly significant at $P<0.005$; ${ }^{d}$ very highly significant at $P<0.001$; ${ }^{e}$ non-significant at $P>0.05$; independent $t$-test; 'one-way ANOVA; ${ }^{2} 27$ students had data missing. Mean total score of SPL was 31.6, maximum =48; mean total score of SPT was 29.3, maximum =44; mean total score of SASP was 20.2, maximum =32; mean total score of SPA was 30.2, maximum $=48$; mean total score of SSSP was 16.6 , maximum $=28$ points.

Abbreviations: SPL, students' perceptions of learning; SPT, students' perceptions of teaching; SASP, students' academic self-perceptions; SPA, students' perceptions of atmosphere; SSSP, students' social self-perceptions; SD, standard deviation; DREEM, the Dundee Ready Education Environment Measure; UniSZA, Universiti Sultan Zainal Abidin; ANOVA, Analysis of variance. 
Table 6 Domain interpretation score of DREEM by medical students of UniSZA according to academic phase $(n=195)$

\begin{tabular}{|c|c|c|c|}
\hline \multirow{2}{*}{$\begin{array}{l}\text { Level of score based } \\
\text { on domain }\end{array}$} & \multicolumn{3}{|c|}{ Number of respondents, $\mathbf{n}(\%)$} \\
\hline & Pre-clinical & Clinical & Overall \\
\hline \multicolumn{4}{|c|}{ Students' perceptions of learning } \\
\hline Very poor & $0(0)$ & $0(0)$ & $0(0)$ \\
\hline $\begin{array}{l}\text { Teaching is viewed } \\
\text { negatively }\end{array}$ & $10(9.8)$ & $4(4.3)$ & $14(7.2)$ \\
\hline $\begin{array}{l}\text { A more positive } \\
\text { approach }\end{array}$ & $82(80.4)$ & $82(88.2)$ & $164(84.1)$ \\
\hline $\begin{array}{l}\text { Teaching highly } \\
\text { thought of }\end{array}$ & $10(9.8)$ & $7(7.5)$ & $17(8.7)$ \\
\hline \multicolumn{4}{|c|}{ Students' perceptions of teaching } \\
\hline Abysmal & $0(0)$ & $0(0)$ & $0(0)$ \\
\hline $\begin{array}{l}\text { In need of some } \\
\text { retraining }\end{array}$ & $4(3.9)$ & $8(8.6)$ & $12(6.2)$ \\
\hline $\begin{array}{l}\text { Moving in the right } \\
\text { direction }\end{array}$ & $83(81.4)$ & 71 (76.3) & I $54(79.0)$ \\
\hline Model teachers & $15(14.7)$ & $14(15.1)$ & $29(14.9)$ \\
\hline \multicolumn{4}{|c|}{ Students' academic self-perceptions } \\
\hline Feeling of total failure & $0(0)$ & $\mathrm{I}(\mathrm{I} . \mathrm{I})$ & $\mathrm{I}(0.5)$ \\
\hline Many negative aspects & $9(8.8)$ & $8(8.6)$ & $17(8.7)$ \\
\hline $\begin{array}{l}\text { Feeling more on the } \\
\text { positive side }\end{array}$ & $80(78.4)$ & $78(83.9)$ & I58 (8I.0) \\
\hline Confident & $13(12.7)$ & $6(6.5)$ & $19(9.7)$ \\
\hline \multicolumn{4}{|c|}{ Students' perceptions of atmosphere } \\
\hline A terrible environment & $0(0)$ & $\mathrm{I}(\mathrm{I} . \mathrm{I})$ & $\mathrm{I}(0.5)$ \\
\hline $\begin{array}{l}\text { There are many issues } \\
\text { that need changing }\end{array}$ & $8(7.8)$ & $8(8.6)$ & $16(8.2)$ \\
\hline $\begin{array}{l}\text { A more positive } \\
\text { atmosphere }\end{array}$ & $82(80.4)$ & $80(86.0)$ & $162(83.1)$ \\
\hline A good feeling overall & $12(11.8)$ & $4(4.3)$ & $16(8.2)$ \\
\hline \multicolumn{4}{|c|}{ Students' social self-perceptions } \\
\hline Miserable & $0(0)$ & $\mathrm{I}(\mathrm{I} . \mathrm{I})$ & $\mathrm{I}(0.5)$ \\
\hline Not a nice place & $25(24.5)$ & $18(19.4)$ & $43(22.1)$ \\
\hline Not too bad & $68(66.7)$ & $73(78.5)$ & $|4|(72.3)$ \\
\hline Very good socially & $9(8.8)$ & $\mathrm{I}(\mathrm{I} . \mathrm{I})$ & $10(5.1)$ \\
\hline
\end{tabular}

Abbreviations: DREEM, the Dundee Ready Education Environment Measure; UniSZA, Universiti Sultan Zainal Abidin.

(72\%). A higher percentage of clinical students favored the UniSZA environment more than the pre-clinical students in all subscales, except perception of teaching (Table 4).

\section{Overall scores}

The overall mean DREEM scores (Table 5) were significantly higher $(P<0.001)$ for females $(131.1 \pm 14.9$ points) than for males (120.7 \pm 17.9 points). Thus, female students indicated a more positive perception than their male counterparts about the UniSZA educational environment.

\section{Students' perceptions of learning}

The mean SPL score indicated that there was a significant difference $(P<0.001)$ between the sexes (SPL score for males was $29.8 \pm 5.37$ points; SPL score for females was $32.4 \pm 3.92$ points) in perceptions of learning at UniSZA's medical school. However, there was also no significant difference $(P=0.386)$ observed between learning phases (preclinical phase, $31.3 \pm 4.97$ points; clinical phase, $31.8 \pm 4.07$ points). Similarly, in terms of the SPL domain, no significant differences $(P>0.05)$ were observed in other sociodemographic or educational parameters (Table 5).

\section{Students' perceptions of teaching}

The mean SPT score indicates that there was a significant difference $(P<0.001)$ between sexes (SPT for males was $27.3 \pm 4.32$ points; SPT for females was $30.6 \pm 4.25$ points) in the medical school student population. There was also significant difference $(P=0.005)$ in mean SPT score when compared with the same students' mean score generated from their evaluation of background foundation studies. The DREEM scores were significantly higher among students who had completed foundation studies (31.7 \pm 4.04 points) than for students who participated in a matriculation program. Among those who participated in the matriculation program, the 1-year graduates scored higher ( $29.2 \pm 4.43$ points) than those who participated in the 2-year program (25.6 \pm 3.15 points). However, no significant differences $(P>0.05)$ were observed due to marital status, race, year of study, cumulative grade point average, or type of secondary school (Table 5).

\section{Students' academic self-perceptions}

The mean SASP score indicated that there was a significant difference $(P=0.004)$ in the sexes' perceptions (mean score for males, $19.1 \pm 3.93$ points; mean score for females $20.6 \pm 2.96$ points). However, no significant differences $(P>0.05)$ were observed in the remaining seven parameters (Table 5).

\section{Students' perceptions of atmosphere}

The mean SPA indicated that there was a significant difference $(P=0.038$ ) between sexes (mean score for males was 29.1 \pm 5.59 points; mean score for female students was $30.7 \pm 4.71$ points). Significant difference $(P=0.005)$ was observed among races. For Indians, the mean SPA score was $33 \pm 5.51$ points, followed by Malays at $30 \pm 4.47$ points. The SPA score for the ethnic category of others was $28.5 \pm 2.08$ points, and the mean SPA score for Chinese students was $28.5 \pm 6.50$ points. The remaining six social and educational considerations showed no significant differences $(P>0.05)$ (Table 5). 


\section{Students' social self-perceptions}

The mean SSSP score indicated that there was a significant sex-related difference $(P<0.001)$ in perceptions (the mean score for males was $15.3 \pm 3.15$ points, and the mean female score for females was $17.2 \pm 3.01$ points). However, other socio-demographic and educational parameters showed no significant difference $(P>0.05)$ in the SSSP domain at the medical school of UniSZA (Table 5).

\section{Discussion}

The aim of this study was to understand and examine the educational environment offered by the Faculty of Medicine and Health Sciences, UniSZA, through the eyes of undergraduates as per feedback provided by the students. The findings were used to identify strengths and weaknesses in the institution's educational environment. A medical school is an environment in which students anticipate experiencing real-life learning activities. Curriculum is the most important determinant of the learning environment, and it controls the behavior of all stakeholders. ${ }^{58,59}$ Any curriculum change should also involve changes in educational environment, management, and the organization to result in the predicted outcomes. Improvement in the educational environment and curriculum is only possible by identifying weaknesses and strengths in both. Monitoring the perception of students of their educational environment is also crucial. ${ }^{41}$ DREEM is an instrument used to assess the educational microclimate and macroclimate of medical schools as perceived by the students. ${ }^{12,32}$

\section{Overall scores}

The overall mean DREEM score in the current study was $127.9 \pm 16.58$ points. Study findings were within the accepted range of 101-150 points that is an indicative of a "more positive than negative" perception. ${ }^{57}$ Overall scores from the current study were analogous with results from institutions in the UK, Nepal, Nigeria, Saudi Arabia, United Arab Emirates (UAE), Yemen, Kuwait, and Iran. ${ }^{39,60-66}$ The University Kebangsaan Malaysia (UKM) and the Universiti Sains Malaysia (USM) scores were quite similar with scores generated at UniSZA..$^{28,44}$

\section{Students' perceptions of learning}

Item 16 (Table 3) in the SPL domain obtained the highest score at UniSZA, which indicates that students believe teaching is helpful in developing skills needed in their profession. On the other hand, the item 25 (Table 3) score was very low. However, none of the items received a very high score, indicating that there is a need for improvement. There was no statistically significant difference $(P=0.386)$ in the mean score between pre-clinical and clinical students (Table 5). This result indicates that the learning methods used by students are suitable and are adapted to their curriculum. Female students' responses were statistically significantly $(P<0.001)$ in their positive perception of learning, as compared to males (Table 5). It has been reported from Michigan State University, East Lansing, MI, USA that there have been differences observed in learning styles between male and female undergraduates. ${ }^{67}$ Furthermore, females generally spend more time studying, compared to males. The overall scores generated at UniSZA were quite similar with scores generated by a number of other studies..$^{37,44,56}$ There were two negative statements made by students regarding SPL. Students complained about "over emphasizes factual learning and too much teacher-centered teaching" at UniSZA. UniSZA managers must put more emphasis on improving these weaknesses and on ensuring future development of the total educational environment of UniSZA.

\section{Students' perceptions of teaching}

Items 2 and 40 (Table 3 ) in the SPT domain scored quite highly, and remaining items scored in the above-average range. This result shows that students are satisfied and able to adapt to the teaching style provided by the lecturers. It also signifies that teaching standards at UniSZA are moderately good. No research participants scored well in the SPT domain. Therefore, students expect some improvement in teaching methodology.

There was no statistically significant difference $(P=0.696)$ in the mean SPT score between pre-clinical and clinical students (Table 5). The teaching style in clinical education is more practical, and in pre-clinical education, it is more theoretical. This finding can be interpreted as an endorsement of effective teaching, with similar satisfaction at different educational phases supporting the interpretation.

Students from the 1-year matriculation program have more positive perceptions, as compared to those who participated in the 2-year matriculation program (Table 5). The 1-year matriculation students probably cope better with the ME system than their peers. This may be one reason that causes 2-year matriculation students to face more difficulties in medical-school. In Malaysia, 2-year matriculation is considered to be a program for relatively weak students.

Female medical students demonstrated more positive perceptions toward teaching; their mean SPT score was sig- 
nificantly higher than their male counterparts' mean score $(P<0.001)$. Research findings show that female students develop more trust toward their lecturers when compared with males. ${ }^{68}$

The overall scores were quite similar with a number of other studies. ${ }^{39,64}$ There were four items $(8,9,39$, and 50$)$ that generated negative statements (Table 3). Those items included statements like "teachers ridicule the students", "are authoritarian", "get angry" and that "students irritate teachers". These issues will damage the quality of teaching and learning programs of UniSZA. Therefore, university authorities should initiate some training plan to resolve these issues.

\section{Students' academic self-perception}

Items 31 and 45 (Table 3) scored well in SASP, but Item 27 scored below average. This can be ascribed to the possible fact that students have confidence in their academic performance, but encounter difficulties in memorizing facts and data, which are critical in the medical field. Therefore, certain policies need to be implemented by the medical faculty at UniSZA to address this issue. Both pre-clinical and clinical students reported similar SASP scores, with no statistically significant differences ( $P=0.906$; Tables 4 and 6$)$. The female students scored better, and their scores were significantly different than male students' scores ( $P=0.004$; Table 5). This finding is supported by research on sex-related differences in another educational institute. ${ }^{69}$ The overall score $(20.1 \pm 3.35$ points) for SASP was somewhat higher in the current study than it was in studies conducted in Saudi Arabia and Kuwait. ${ }^{63,65}$

\section{Students' perceptions of atmosphere}

SPA is very important, because it influences all aspects of teaching and learning. All the items from this domain scored above-average at UniSZA, which indicates that research participants have positive perceptions. However, none of the items scored very well. The policy makers of UniSZA should concentrate more on leisure activities and encouraging didactic settings. Females' perceptions regarding SPA were significantly different $(P=0.038)$ than male students' perceptions. Previous study results have shown that females have better coping strategies and adapt more readily than their male colleagues. ${ }^{70,71}$ The present study also exhibited that Indian students have a significantly better ability to cope with the ME milieu, followed by Malays, Chinese, and others $(P=0.005)$. The overall SPA scores were comparable to scores generated in an Irish study, ${ }^{10}$ but a bit higher than scores achieved in a study in Kuwait. ${ }^{65}$ There were two negative statements (items 17, 35, Table 3). Student reported cheating and disappointment. The authors expect that with more intensive care in the future, these two issues can be improved in the near future.

\section{Students' social self-perceptions}

Item 15 (Table 3) is the item in the SSSP domain with highest score. Item 3 and 14 scores were low. Other items achieved average scores. These findings prove that students depend mostly on their friends for their social and moral support. There was only one negative item reported, number 14, regarding SSSP. UniSZA medical students were "rarely bored", but students claimed that the UniSZA system does not provide adequate opportunities to manage stress, and also that social opportunities are inadequate. The authors expect that UniSZA will engineer more opportunities for students to relax and improve their social life. Male students disclosed a statistically significant, less positive perception when compared to females $(P<0.001)$. Females are more emotionally attached to their friends in many aspects, whereas males are only attached to enjoyable activities, but are not proactive in sharing problems with friends. ${ }^{72}$ The overall scores for UniSZA in the SSSP domain were comparable to an equivalent Irish study, ${ }^{10}$ but were slightly higher than scores generated in a study in Kuwait ${ }^{65}$ Malaysia is a multi-ethnic country with a multi-cultural society; in fact, the UniSZA social environment was perceived to be well-balanced between Malay, Chinese, and Indian students. Current findings were very similar with another study of Malaysian student perceptions. ${ }^{28}$

\section{Study limitations}

This is a cross-sectional study with its own inherent limitations. The number of participants who returned the questionnaire varied among the year of study. Only 195 out of 270 students responded to the questionnaire. This lower response rate was due to the fact that when the study was conducted, some students were busy with exam preparations, and others had returned home for the semester break.

\section{Conclusion}

The medical students of UniSZA showed a positive perception of their MBBS program and educational environment. The Faculty of Medicine and Health Sciences of UniSZA, within a few years, has achieved an above-average, conducive learning environment for their students. Most of the students showed a positive perception in the entire five domains tested in the DREEM questionnaire. Female medical 
students were consistently satisfied with UniSZA's educational environment, as compared to their male undergraduate counterparts.

A regular evaluation process of the students' perceptions is necessary to obtain continual information feedback from them and other stakeholders, so that the learning environment can be improved to support consistently effective learning and teaching. Also, initial mistakes can be corrected easily, and a proper learning pace can be conserved. This appraisal will provide baseline data and guidelines in areas that students feel good about, which should be reinforced, and in the weaker areas, which need improvement. Well-planned, prospective follow-up research is advocated in this regard. Consequently, the medical faculty of UniSZA can improve immensely, and can be the best among medical universities of Malaysia. Improved and consistent performance will enable UniSZA to produce more holistic doctors who are better prepared to serve the people of Malaysia and the rest of the world.

\section{Acknowledgments}

The authors are very grateful to those medical students who participated in the study. The authors are very grateful to Mr Abdullahi Rabiu Abubakar, Master Student, Faculty of Medicine and Health Sciences, UniSZA, Kuala Terengganu, Malaysia and also Dr Ashraful Huq, Medical Director, Program of Assertive Community Treatment (PACT), Hampton, VA, USA for help with manuscript preparation.

\section{Disclosure}

The authors report no conflicts of interest in this work.

\section{References}

1. Rahman NIA, Ismail S, Seman TNABT, et al. Stress among preclinical medical students of University Sultan Zainal Abidin. J App Pharma Sci. 2013;3(11):76-81.

2. Salam A, Yousuf R, Bakar SA, Haque M. Stress among medical students in Malaysia. A systematic review of literatures. Int Med J. 2013;20(6): 649-655.

3. Rahman NIA, Ismail SB, Ali RM, et al. Stress among first batch of MBBS students of Faculty of Medicine and Health Sciences, Universiti Sultan Zainal Abidin, Malaysia: When final professional examination is knocking the door. Int Med J. In press 2015.

4. Divaris K, Barlow PJ, Chendea SA, et al. The academic environment: the students' perspective. Eur J Dent Educ. 2008;12(Suppl 1):120-130.

5. Salam A, Yousuf R, Islam MZ, et al. Professionalism of future medical professionals in Universiti Sultan Zainal Abidin, Malaysia. Bangladesh J Pharmacol. 2013;8(2):124-130.

6. Salam A, Haque M, Islam MZ, et al. Comparative Study of Professionalism of Future Medical Professionals among Three Private Medical Colleges of Bangladesh. Asian J Pharm Clin Res. 2013;6(3):170-179.

7. Salam A, Haque M, Helali AM, et al. Comparative study on professionalism of forthcoming medical doctors between two private medical colleges In Savar, Bangladesh. Int J Pharm Pharm Sci. 2013;5(Suppl 3):659-665.
8. Islam MZ, Salam A, Helali AM, et al. Comparative study of professionalism of future medical doctors between Malaysia and Bangladesh. J App Pharm Sci. 2014;4(04):066-071.

9. Wikipedia.org. [page on the Internet]. Environment. Wikipedia; 2014. Available from: http://simple.wikipedia.org/wiki/Environment. Accessed November 12, 2014.

10. Avalos G, Freeman C, Dunne F. Determining the quality of the medical educational environment at an Irish Medical School using the DREEM inventory. Ir Med J. 2007;100(7):522-525.

11. Genn JM. AMEE Medical Education Guide No 23 (Part 2): curriculum, environment, climate quality and change in medical education - a unifying perspective. Med Teach. 2001;23(5):445-454.

12. Roff S, Mcaleer S. What is educational climate? Med Teach. 2001; 23(4):333-334.

13. Harden RM. The learning environment and the curriculum. Med Teach. 2001;23(4):335-336.

14. Genn JM. AMEE Medical Education Guide No 23 (Part 1): curriculum, environment, climate, quality and change in medical education unifying perspective. Med Teach. 2001;23(4):337-344.

15. Whittle SR, Whelan B, Murdoch-Eaton DG. DREEM and beyond; studies of the educational environment as a means for its enhancement. Educ Health (Abingdon). 2007;20(1):7.

16. Audin K, Davy J, Barkham M. University Quality of Life and Learning (UNIQoLL): an approach to student wellbeing, satisfaction and institutional change. J Further High Educ. 2003;27(4):365-382.

17. Finn Y, Avalos G, Dunne F. Positive changes in the medical educational environment following introduction of a new systems-based curriculum: DREEM or reality? Curricular change and the Environment. Ir J Med Sci. 2014;183(2):253-258.

18. Hutchinson L. Educational environment. BMJ. 2003;326:810-812.

19. Tontus HO. DREEM; dreams of the educational environment as its effect on education result of 11 medical faculties of Turkey. J Exp Clin Med. 2010;27:104-108.

20. Bassaw B, Roff S, McAleer S, et al. Students' perspectives on the educational environment, Faculty of Medical Sciences, Trinidad. Med Teach. 2003;25(5):522-526.

21. Rothman AI, Ayoade F. The development of a learning environment: a questionnaire for use in curriculum evaluation. J Med Educ. 1970; 45(10):754-759.

22. Marshall RE. Measuring the medical school learning environment. J Med Educ. 1978;53(2):98-104.

23. Feletti GI, Clarke RM. Review of psychometric features of the medical school learning environment survey. Med Educ. 1981;15(2):92-96.

24. Moore-West M, Harrington DL, Mennin SP, Kaufman A, Skipper BJ. Distress and attitudes toward the learning environment: effects of a curriculum innovation. Res Med Educ. 1986;25:293-300.

25. General Medical Council. Tomorrow's Doctors. Outcomes and Standards for Undergraduate Medical Education. Manchester: General Medical Council; 2009. Available from: http://www.gmc-uk.org/ Tomorrow_s_Doctors_0414.pdf_48905759.pdf. Accessed November 16, 2014.

26. Chan DSK. Combining qualitative and quantitative methods in assessing hospital learning environments. Int J Nurs Stud. 2001;38(4): 447-459.

27. Mulrooney A. Development of an instrument to measure the practice vocational training environment in Ireland. Med Teach. 2005;27(4): 338-342.

28. Salam A, Akram A, Bujang AM, et al. Educational environment in a multicultural society to meet the challenges of diversity. J App Pharm Sci. 2014;4(09):110-113.

29. Yusoff MSB. The Dundee Ready Educational Environment Measure: a confirmatory factor analysis in a sample of Malaysian medical students. Int J Humanit Soc Sci. 2012;2(16):313-321.

30. Dent JA, Harden RM. A Practical Guide for Medical Teachers. 3rd ed. Edinburgh: Elsevier Churchill Livingstone; 2009.

31. Newble D, Cannon RA, Kapelis ZA. A Handbook for Medical Teachers. 4th ed. New York: Kluwer Academic Publishers; 2001. 
32. Roff S, McAleer S, Harden RM, et al. Development and validation of the Dundee Ready Education Environment Measure (DREEM). Med Teach. 1997;19(4):295-299.

33. Swift L, Miles S, Leinster SJ. The analysis and reporting of the Dundee Ready Education Environment Measure (DREEM): some informed guidelines for evaluators. Creative Education. 2013;4(5):340-347.

34. Kiran HS, Gowdappa BH. "DREEM" comes true - students' perceptions of educational environment in an Indian medical school. $J$ Postgrad Med. 2013;59(4):300-305.

35. Kossioni AE, Varela R, Ekonomu I, Lyrakos G, Dimoliatis IDK. Students' perceptions of the educational environment in a Greek Dental School, as measured by DREEM. Eur J Dent Educ. 2012;16(1): e73-e78.

36. Jeyashree K, Patro BK. The potential use of DREEM in assessing the perceived educational environment of postgraduate public health students. Med Teach. 2013;35(4):339-340.

37. Tripathy S, Dudani S. Students' perception of the learning environment in a new medical college by means of the DREEM inventory. Int $J$ Res Med Sci. 2013;1(4):385-391.

38. Al-Hazimi A, Al-Hyiani A, Roff S. Perceptions of the educational environment of the medical school in King Abdul Aziz University, Saudi Arabia. Med Teach. 2004;26(6):570-573.

39. Thomas BS, Abraham RR, Alexander M, Ramnarayan K. Students' perceptions regarding educational environment in an Indian dental school. Med Teach. 2009;31(5):e185-e186.

40. Varma R, Tiyagi E, Gupta J. Determining the quality of educational climate across multiple undergraduate teaching sites using the DREEM inventory. BMC Med Educ. 2005;5(1):8.

41. Al-Naggar RA, Abdulghani M, Osman MT, et al. The Malaysia DREEM: perceptions of medical students about the learning environment in a medical school in Malaysia. Adv Med Educ Prac. 2014;5:177-184.

42. Said NM, Rogayah J, Hafizah A. A study of learning environments in the Kulliyyah (Faculty) of Nursing, International Islamic University Malaysia. Malays J Med Sci. 2009;16(4):15-24.

43. Yusoff MSB. Stability of DREEM in a sample of medical students: a prospective study. Educ Res Int. 2012;509638.

44. Arzuman H, Yusoff MSB, Chit SP. Big Sib students' perceptions of the educational environment at the School of Medical Sciences, Universiti Sains Malaysia, using Dundee Ready Educational Environment Measure (DREEM) inventory. Malays J Med Sci. 2010;17(3):40-47.

45. Plucker JA. The relationship between school climate conditions and student aspirations. J Educ Res. 1998;91(4):240-246.

46. Lizzio A, Wilson K, Simons R. University students' perceptions of the learning environment and academic outcomes: implications for theory and practice. Stud High Educ. 2002;27(1):27-52.

47. Mayya SS, Roff S. Students' perceptions of educational environment: a comparison of academic achievers and under-achievers at Kasturba Medical College, India. Educ Health (Abingdon). 2004;7(3): 280-291.

48. Genn JM, Harden R. What is medical education here really like? Suggestions for action research studies of comates of medical education environments. Med Teach. 1986;8(2):111-124.

49. Miles S, Swift L, Leinster SJ. The Dundee Ready Education Environment Measure (DREEM): a review of its adoption and use. Med Teach. 2012;34(9):e620-e634.

50. Brown T, Williams B, Lynch M. The Australian DREEM: evaluating student perceptions of academic learning environments within eight health science courses. Int J Med Educ. 2011;2:94-101.

51. Bertram D. Likert Scales are the meaning of life. Available from: http://poincare.matf.bg.ac.rs/ kristina/topic-dane-likert.pdf. Accessed February 11, 2015

52. Chandana NGASS, Hettiarachchi M. Educational environment of nursing undergraduates in University of Ruhuna: effect of gender. J Univ Ruhuna. 2013;1(1):11-16.

53. Roff S. The Dundee Ready Educational Environment Measure (DREEM) - a generic instrument for measuring students' perceptions of undergraduate health professions curricula. Med Teach. 2005;27(4): $322-325$.
54. Soemantri D, Herrera C, Riquelme A. Measuring the educational environment in health professions studies: a systematic review. Med Teach. 2010;32(12):947-952.

55. Jiffry MT, McAleer S, Fernando S, Marasinghe RB. Using the DREEM questionnaire to gather baseline information on an evolving medical school in Sri Lanka. Med Teach. 2005;27(4):348-352.

56. Abraham R, Ramnarayan K, Vinod P, Torke S. Students' perceptions of learning environment in an Indian medical school. BMC Med Educ. 2008;8:20.

57. McAleer S, Roff S. A practical guide to using the Dundee Ready Education Environment Measure (DREEM). In: Genn JM, editor AMEE Medical Education Guide No 23 Curriculum, Environment, Climate, Quality and Change in Medical Education; A Unifying Perspective. Dundee: Association of Medical Education in Europe; 2001:29-33.

58. Demirören M, Palaoglu Ö, Kemahli S, Özyurda F Ayhan HI. Perceptions of students in different phases of medical education of educational environment: Ankara University Faculty of Medicine. Med Educ Online. 2008;13:8. Available from http://www.med-ed-online.org. Accessed on February 18, 2015

59. Unnikrishnan B, Rekha T, Mithra PP, Kumar N, Reshmi B. Perceptions of Medical Students about their Educational Environment in Community Medicine in a Medical College of Coastal Karnataka. Indian J Community Med. 2012;37(2):130-132. Available from http://www. ncbi.nlm.nih.gov/pmc/articles/PMC3361797/. Accessed on February $18,2015$.

60. Al-Hazimi A, Zaini R, Al-Hyiani A, et al. Educational environment in traditional and innovative medical schools: a study in four undergraduate medical schools. Educ Health (Abingdon). 2004;17(2): 192-203.

61. Roff S, McAleer S, Ifere OS, Bhattacharya S. A global diagnostic tool for measuring educational environment: comparing Nigeria and Nepal. Med Teach. 2001;23(4):378-382.

62. Zawawi AH, Elzubeir M. Using DREEM to compare graduating student's perceptions of learning environments at medical schools adopting contrasting educational strategies. Med Teach. 2012;34(S1): $\mathrm{S} 25-\mathrm{S} 31$.

63. Al-Ayed IH, Sheik SA. Assessment of the educational environment at the College of Medicine of King Saud University, Riyadh. East Mediterr Health J. 2008;14(4):953-959.

64. Shehnaz SI, Sreedharan J. Students' perceptions of educational environment in a medical school experiencing curricular transition in United Arab Emirates. Med Teach. 2011;33(1):e37-e42.

65. Bouhaimed M, Thalib L, Doi SAR. Perception of the educational environment by medical students undergoing a curricular transition in Kuwait. Med Princ Prac. 2009;18(3):204-208.

66. Bakhshi H, Bakhshialiabad MH, Hassanshah GH. Students' perceptions of the educational environment in an Iranian Medical School, as measured by The Dundee Ready Education Environment Measure. Bangladesh Med Res Counc Bull. 2014;40:36-41.

67. Wehrwein EA, Lujan HL, DiCarlo SE. Gender differences in learning style preferences among undergraduate physiology students. $A d v$ Physiol Educ. 2007;31(2):153-157.

68. Schulte-Pelkum JV, Schweer MKW, Pollak B. Dyadic trust relations between teachers and students - an empirical study about conditions and effects of perceived trustworthiness in the classroom from a differential perspective. Beziehungen in Unterricht und Schule. 2014;9(5):1-14.

69. Voyer D, Voyer SD. Gender differences in scholastic achievement: A meta-analysis. Psychol Bull. 2014;140(4):1174-1204.

70. Matud MP. Gender differences in stress and coping styles. Pers Indiv Diff. 2004;37(7):1401-1415.

71. Tamres LK, Janicki D, Helgeson VS. Sex differences in coping behavior: a meta-analytic review and an examination of relative coping. Pers Soc Psychol Rev. 2002;6(1):2-30.

72. Bell RR. Friendships of women and of men. Psychol Women Quart. 1981;5(3):402-417. 
Video abstract

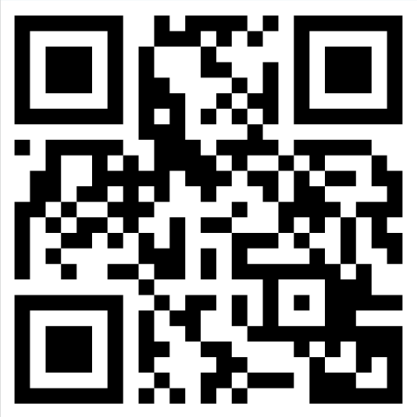

Point your SmartPhone at the code above. If you have a

QR code reader the video abstract will appear. Or use: http://dvpr.es//zz2rME

\section{Publish your work in this journal}

Advances in Medical Education and Practice is an international, peerreviewed, open access journal that aims to present and publish research on Medical Education covering medical, dental, nursing and allied health care professional education. The journal covers undergraduate education, postgraduate training and continuing medical education including emerging trends and innovative models linking education, research, and health care services. The manuscript management system is completely online and includes a very quick and fair peer-review system. Visit http://www.dovepress.com/testimonials.php to read real quotes from published authors.

Submit your manuscript here: http://www.dovepress.com/advances-in-medical-education-and-practice-journal 